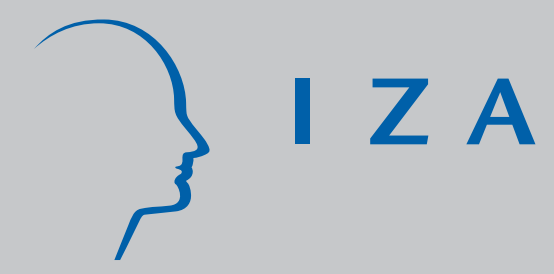

IZADP No. 1915

The Economics of Dual J ob Holding: A J ob Portfolio Model of Labor Supply

Francesco Renna

Ronald L. Oaxaca

J anuary 2006 


\title{
The Economics of Dual Job Holding: A Job Portfolio Model of Labor Supply
}

\author{
Francesco Renna
}

University of Akron

Ronald L. Oaxaca

University of Arizona

and IZA Bonn

\section{Discussion Paper No. 1915 \\ January 2006}

\author{
IZA \\ P.O. Box 7240 \\ 53072 Bonn \\ Germany
}

\author{
Phone: +49-228-3894-0 \\ Fax: +49-228-3894-180 \\ Email: iza@iza.org
}

\begin{abstract}
Any opinions expressed here are those of the author(s) and not those of the institute. Research disseminated by IZA may include views on policy, but the institute itself takes no institutional policy positions.

The Institute for the Study of Labor (IZA) in Bonn is a local and virtual international research center and a place of communication between science, politics and business. IZA is an independent nonprofit company supported by Deutsche Post World Net. The center is associated with the University of Bonn and offers a stimulating research environment through its research networks, research support, and visitors and doctoral programs. IZA engages in (i) original and internationally competitive research in all fields of labor economics, (ii) development of policy concepts, and (iii) dissemination of research results and concepts to the interested public.
\end{abstract}

IZA Discussion Papers often represent preliminary work and are circulated to encourage discussion. Citation of such a paper should account for its provisional character. A revised version may be available directly from the author. 
IZA Discussion Paper No. 1915

January 2006

\section{ABSTRACT}

\section{The Economics of Dual Job Holding: A Job Portfolio Model of Labor Supply*}

In this paper we develop a job portfolio model of dual job holding based on a Stone-Geary utility function. We derive the associated Slutsky equation components. Because the job portfolio model applies only to unconstrained dual jobholders, we separate individuals who moonlight because of an hours constraint from dual jobholders who work on two job for reasons different from an hours constraint. Income and wage elasticities are estimated for workers without hours constraints using data from the May 1991 supplement to the Current Population Survey. Our study finds that the income and compensated wage elasticities are much larger for labor supply to job 2 compared with job 1.

JEL Classification: $\quad$ J22

Keywords: dual job, labor supply, Stone-Geary

Corresponding author:

Ronald L. Oaxaca

Department of Economics

University of Arizona

P.O. Box 210108

Tucson, AZ 85721-0108

USA

Email: rlo@email.arizona.edu

\footnotetext{
*We gratefully acknowledge the helpful comments of seminar participants at Case Western University.
} 


\section{INTRODUCTION}

Researchers have progressively extended labor supply theory in both static and dynamic dimensions to account for a richer variety of labor supply behavior. One fruitful area for research on labor supply is that of multiple job holding. The incidence of multiple job holdings peaked in 1996 with 6.2 percent of the American labor force reporting two jobs according to the Bureau of Labor Statistics (Campbell, 2003). More recently the rate of dual job holding has decreased, but it was still as high as 5.3 percent in 2002. These rates refer to the incidence of dual job holding in a typical

work week. Since different people can hold two jobs within a reporting week, the annual rate of multiple jobholding is much higher than the weekly rate. For example, using the Panel Study of Income Dynamics, Paxon and Sicherman (1996) calculated that on average 20 percent of working males and 12 percent of working females held two jobs each year between 1976 and 1989. Not only is dual job holding very common, it also comprises a large part of total production in the U.S. In fact, about 17 percent of total annual hours of work consist of hours worked on a second job (Paxon and Sicherman, 1996).

Dual job holding is usually associated with an hours constraint on the main job. Firms often offer a fixed hours and wage employment package. If the number of hours a firm offers falls short of the optimal number of hours that a utility maximizing worker would choose at the going wage, then a rational individual will take a second job under the condition that it pays more than his reservation wage on the second job. This is what we regard as the hours constraint motivation for holding multiple jobs. However, some individuals may decide to allocate their working time between two or more jobs not because there is a market constraint on their desired hours in any given job (or perhaps an hours constraint for a working spouse), but because they have a personal preference for job differentiation. Under this scenario, the individual has to 
decide how to allocate his or her working time among alternative employments. This is what we refer to as the job portfolio motive for multiple job holding. In this paper we develop a job portfolio model of dual job holding based on a Stone-Geary utility function.

To date the economics literature on multiple job holdings is still relatively sparse. Early theoretical work focused only on the hours constraint aspect of moonlighting. Shisko and Rostker (1976) found that the labor supply becomes more elastic to changes of the wage rate after accounting for the decision to moonlight as a response to an hours constraint on the primary job. Following this line of research, Abdukadir (1990) found evidence that the presence of a liquidity constraint, as deriving from the decision to buy a house or a new car, increases the probability of taking a second job. Analyzing the labor market choices of a husband and wife within a household labor supply framework, Krishnan (1990) found that the husband's decision to hold a second job is a substitute for the wife entering the labor market. Paxon and Sicherman (1996) also found that dual jobholding is an immediate solution to a situation of under-employment, while searching for a job that offers the target hours of work.

Dual jobholding, however, is not only related to hours constraints. In the 1997 U.S. Current Population Survey only 59 percent of multiple job holders reported that the reason for moonlighting was some form of hours or liquidity constraints (see Kimmel and Powell, Table 7). Convay and Kimmel (1998) first attempted to estimate a moonlighting labor supply model that incorporates both the job portfolio motive and constrained hours as possible reasons for holding two jobs. Since their data set does not contain information about the motivation for holding two jobs, the authors estimate first the probability that a moonlighter faces an hour constraint on the main occupation, and then use this result to estimate a switching regression model. In a subsequent paper, Convay and Kimmel (2001) used a different strategy to identify the motivation for holding two jobs, assuming that people with short spells 
of moonlighting would be most likely constrained.

The works by Convay and Kimmel show how difficult it is to identify the motivation for holding two jobs. To avoid this problem Allen (1998) uses the Panel Study of Income Dynamics data set, which explicitly asked the respondents if they desired to work more hours but were unable to do so. The author focused only on unmarried men and women, and interestingly he found that unconstrained workers are more likely to have two jobs than are constrained workers. Similarly, Averett (2001) exploited the information in the 1991 Current Population Survey about the motivation for holding two jobs. She estimated a bivariate probit model of the decision to work and the decision to hold more than one job, and she found that the factors that influence the decision to moonlight are similar for men and women.

The evidence of different motivations behind the decision to hold two jobs points to the need to formalize a model that distinguishes between moonlighting because of an hours constraint on the first job and moonlighting because people prefer to hold multiple jobs. In this paper we develop a job portfolio model of multiple jobholding in a static framework. We specify a Stone-Geary utility function to motivate the empirical work in the context of a dual job holding model. The Stone-Geary utility function has been widely used to estimate expenditure functions for multiple commodity groups. ${ }^{1}$ Herein, we use the Stone-Geary utility function to derive the system of supply equations for individuals who decide to hold multiple jobs. No attempt is made to estimate the labor supply for constrained workers, since the Stone-Geary utility function describes only the preference of individuals that prefer to work on more than one job. On the contrary the utility function of a constrained moonlighter is defined only over one job: if one could remove the constraint, individuals would maximize their utility function working on only one job. Section II presents the theoretical specification; section III describes the data; section IV describes the esti-

\footnotetext{
${ }^{1}$ See Chung (1994) for a review of the main studies based on a Stone-Geary utility function.
} 
mation strategies and presents the empirical findings; and section IV offers concluding remarks.

\section{Conceptual Framework}

Consider utility maximization for a multiple job holder who is not constrained in his choice of hours to work at the various jobs. To make things concrete we will consider a Stone-Geary utility function for two different jobs or tasks:

$$
U=\left(\gamma_{1}-h_{1}\right)^{\alpha_{1}}\left(\gamma_{2}-h_{2}\right)^{\alpha_{2}}\left(y-\gamma_{3}\right)^{1-\alpha_{1}-\alpha_{2}}
$$

where $\alpha_{1}, \alpha_{2}, \gamma_{1}, \gamma_{2}, \gamma_{3}>0, h_{j}$ represents the time allocated to job $j$, and $y$ is income. The parameters $\gamma_{1}$ and $\gamma_{2}$ represent the upper bound on the time that can be expended on jobs 1 and 2, and still have the utility function defined. They satisfy the following restriction:

$$
\sum_{j=1}^{2} \gamma_{j}=T
$$

where $T$ is the total time available for work and leisure. The parameter $\gamma_{3}$ represents the lower bound on the amount of income necessary in order to have the utility function defined. The economic problem can be stated as

$$
\begin{aligned}
\max _{h_{1}, h_{2}, y} U & =\left(\gamma_{1}-h_{1}\right)^{\alpha_{1}}\left(\gamma_{2}-h_{2}\right)^{\alpha_{2}}\left(y-\gamma_{3}\right)^{1-\alpha_{1}-\alpha_{2}} \\
\text { s.t. } y & =\sum_{j=1}^{2} w_{j} h_{j}+\mathrm{I}, \\
0 & \leq h_{j}<\gamma_{j}, j=1,2 \text { and } \\
\sum_{j=1}^{2} h_{j} & \leq T
\end{aligned}
$$

where $w_{j}$ is the wage or pecuniary rewards to the $j t h$ job, and I is exogenous, nonlabor income. 
It can be shown that the labor supply functions to the two jobs are given by

$$
h_{1}=\left(1-\alpha_{1}\right) \gamma_{1}-\alpha_{1} \gamma_{2}\left(\frac{w_{2}}{w_{1}}\right)+\alpha_{1} \gamma_{3}\left(\frac{1}{w_{1}}\right)-\alpha_{1}\left(\frac{\mathrm{I}}{w_{1}}\right)
$$

and

$$
h_{2}=\left(1-\alpha_{2}\right) \gamma_{2}-\alpha_{2} \gamma_{1}\left(\frac{w_{1}}{w_{2}}\right)+\alpha_{2} \gamma_{3}\left(\frac{1}{w_{2}}\right)-\alpha_{2}\left(\frac{\mathrm{I}}{w_{2}}\right) \text {. }
$$

Accordingly, the earnings version of the labor supply functions are expressed as

$$
w_{1} h_{1}=\alpha_{1} \gamma_{3}+\left(1-\alpha_{1}\right) \gamma_{1} w_{1}-\alpha_{1} \gamma_{2} w_{2}-\alpha_{1} \mathrm{I}
$$

and

$$
w_{2} h_{2}=\alpha_{2} \gamma_{3}+\left(1-\alpha_{2}\right) \gamma_{2} w_{2}-\alpha_{2} \gamma_{1} w_{2}-\alpha_{2} \mathrm{I}
$$

The uncompensated own wage effect for job $i$ is given by

$$
\frac{\partial h_{i}}{\partial w_{i}}=\frac{\alpha_{i}}{\left(w_{i}\right)^{2}}\left(\gamma_{j} w_{j}+\mathrm{I}-\gamma_{3}\right) \gtreqless 0, i, j=1,2 \text { for } i \neq j,
$$

or in elasticity terms

$$
\begin{aligned}
\eta_{i i} & =\frac{w_{i}}{h_{i}} \frac{\partial h_{i}}{\partial w_{i}} \\
& =\frac{\alpha_{i}}{w_{i} h_{i}}\left(\gamma_{j} w_{j}+\mathrm{I}-\gamma_{3}\right) \gtreqless 0 .
\end{aligned}
$$

Thus, the effect of an uncompensated increase in the own wage for job $i$ can have a positive, negative, or no effect on the labor supply to the ith job. An "inferior" job might be defined as one in which an increase in its wage leads to a reduction in labor supply to the given job and some combination of increases in leisure and labor supplied to the other job, subsidized by the increased return to the given job. The pure income effect for job $i$ is given by

$$
\frac{\partial h_{i}}{\partial \mathrm{I}}=-\frac{\alpha_{i}}{w_{i}}<0
$$


or in elasticity terms

$$
\begin{aligned}
\eta_{i \mathrm{I}} & =\frac{\mathrm{I}}{h_{i}} \frac{\partial h_{i}}{\partial \mathrm{I}} \\
& =-\alpha_{i} \frac{\mathrm{I}}{w_{i} h_{i}}<0
\end{aligned}
$$

so that leisure is a normal good since an increase in non-labor income will reduce the labor supplied to job $i$ (and job $j$ ) and hence increase leisure time. The uncompensated cross wage effect on the supply of labor to job $i$ from a change in the wage for job $j$ is as follows:

$$
\frac{\partial h_{i}}{\partial w_{j}}=-\frac{\alpha_{i} \gamma_{j}}{w_{i}}<0
$$

or in elasticity terms

$$
\begin{aligned}
\eta_{i j} & =\frac{w_{j}}{h_{i}} \frac{\partial h_{i}}{\partial w_{j}} \\
& =-\alpha_{i} \gamma_{j} \frac{w_{j}}{w_{i} h_{i}}<0 .
\end{aligned}
$$

Therefore, an uncompensated increase in the wage for one job reduces the labor supplied to the other.

The compensated own substitution effect for job $i$ can be shown to be

$$
S_{i i}=\frac{\alpha_{i}}{\left(w_{i}\right)^{2}}\left(\gamma_{j} w_{j}+w_{i} h_{i}+\mathrm{I}-\gamma_{3}\right)>\frac{\alpha_{i}}{\left(w_{i}\right)^{2}}\left(y-\gamma_{3}\right)>0
$$

or in elasticity terms the compensated own elasticity is given by

$$
\begin{aligned}
\eta_{i i}^{c} & =\frac{w_{i}}{h_{i}} S_{i i} \\
& =\frac{\alpha_{i}}{w_{i} h_{i}}\left(\gamma_{j} w_{j}+w_{i} h_{i}+\mathrm{I}-\gamma_{3}\right)>0
\end{aligned}
$$

Thus, an increase in the own wage to a job compensated by an offsetting reduction in income necessary to hold utility constant, will increase the supply of labor to that job. This is the own substitution effect from a change in the own wage after removing the income effect. The income effect of the own wage change can be shown to equal 
$-\frac{h_{i} \alpha_{i}}{w_{i}}$. The Slutsky equation decomposing the uncompensated own wage effect is given by

$$
\frac{\partial h_{i}}{\partial w_{i}}=S_{i i}-\frac{h_{i} \alpha_{i}}{w_{i}}
$$

or in elasticity terms

$$
\begin{aligned}
\eta_{i i} & =\frac{w_{i}}{h_{i}} S_{i i}+\epsilon_{i i \mathrm{I}} \\
& =\eta_{i i}^{c}+\epsilon_{i i \mathrm{I}}
\end{aligned}
$$

where $\epsilon_{i i \mathrm{I}}=-\alpha_{i}$ is the income effect elasticity from the own wage. The own substitution effect increases labor supply to job $i$ while the income effect reduces labor supply to the $i t h$ job. The net effect is ambiguous. The compensated cross substitution effect may be expressed as

$$
S_{i j}=\frac{\alpha_{i}}{w_{i}}\left(h_{j}-\gamma_{j}\right)<0
$$

or in elasticity terms

$$
\begin{aligned}
\eta_{i j}^{c} & =\frac{w_{j}}{h_{i}} S_{i j} \\
& =\frac{\alpha_{i} w_{j}}{w_{i} h_{i}}\left(h_{j}-\gamma_{j}\right)<0 .
\end{aligned}
$$

The compensated cross substitution effect implies that an increase in the reward to job $j$ compensated by a reduction in income necessary to hold utility constant, will reduce the supply of labor to job $i$ (and increase the supply of labor to job $j$ ). The income effect of the cross wage change in the $j t h$ job on labor supply to the $i t h$ job can be shown to equal $-\frac{\alpha_{i} h_{j}}{w_{i}}$. The Slutsky equation decomposing the uncompensated cross wage effect is given by

$$
\frac{\partial h_{i}}{\partial w_{j}}=S_{i j}-\frac{\alpha_{i} h_{j}}{w_{i}}
$$

or in elasticity terms

$$
\begin{aligned}
\eta_{i j} & =\frac{w_{j}}{h_{i}} S_{i j}+\epsilon_{i j \mathrm{I}} \\
& =\eta_{i j}^{c}+\epsilon_{i j \mathrm{I}}
\end{aligned}
$$


where $\epsilon_{i j \mathrm{I}}=-\alpha_{i} \frac{w_{j} h_{j}}{w_{i} h_{i}}$ is the cross income effect elasticity of labor supply to the $i t h$ job with respect to a wage change in the $j t h$ job.

The familiar symmetry property of neoclassical theory holds for our Stone-Geary model:

$$
S_{i j}=\frac{\alpha_{i}}{w_{i}}\left(h_{j}-\gamma_{j}\right)=\frac{\alpha_{j}}{w_{j}}\left(h_{i}-\gamma_{i}\right)=S_{j i}<0
$$

This means, for example, that a compensated change in the wage in job 1 has the same effect on labor supply to job 2 as a compensated change in the wage in job 2 has on labor supply to job 1 . This symmetry does not hold in elasticity terms:

$$
\begin{aligned}
\eta_{j i}^{c} & =\frac{w_{i}}{h_{j}} S_{j i} \\
& =\frac{\alpha_{j} w_{i}}{w_{j} h_{j}}\left(h_{i}-\gamma_{i}\right) \\
& =\frac{\alpha_{i}}{h_{j}}\left(h_{j}-\gamma_{j}\right) \\
& \neq \eta_{i j}^{c} .
\end{aligned}
$$

A special case is one in which the wages to jobs 1 and 2 are equal, i.e., $w_{1}=w_{2}=w$. This of course does not imply equal labor supply to both jobs since they may have different utilities (or disutilities) associated with them.

\section{Data}

In this study, we use data from the May 1991 supplement to the Current Population Survey (CPS) entitled "Multiple Job Holding and Work Schedules". While several surveys have collected information about the second job, the CPS May 1991 supplement is the only one we are aware of that directly asked the respondents to report the reason for working on more than one job. This information was necessary for the purpose of our study. Since we focus only on unconstrained workers, we needed to identify and exclude individuals who moonlight because of an hours constraint on the main job from workers that hold two jobs for other reasons. Table 1 reports the 
possible reasons for holding two jobs as listed by the data dictionary of the CPS and the corresponding number of observations in the data set. The most frequently cited reason for holding two jobs is to meet regular household expenses.

We defined as unconstrained any individual who reported having two jobs for any of the following reasons: 1) to obtain experience in a different occupation or to build up a business; 2) to help out a friend or relative ${ }^{2} ; 3$ ) enjoys the work on the second job; or 4) other reasons. We restrict the estimation of our model to males who were not enrolled in school. In our sample there were 1,634 individuals who reported having two jobs during the CPS reference week (almost 7 percent of the total sample). Of these dual job holders, 737 can be associated with the job portfolio motive. Unfortunately the information about the wage rate on the first job is available only for 134 individuals, the information about the wage rate on the second job is available only for 411 individuals, and the non-labor income variable could be computed only for 157 individuals. Once we delete the observations with missing values on any of our variables and those whose reported wages that were either less than $\$ 1 / \mathrm{hr}$ or more than $\$ 100 / \mathrm{hr}$, we obtain 70 observations.

Table 2 lists the variables used in the analysis, including the mean, median, minimum and maximum values. While most of the variables are straightforward, some may require an explanation about how they were constructed. The wage rate was calculated by dividing the weekly earnings by the usual hours worked on the relevant job. This procedure was preferred to the self reported information on the hourly wage rate because it guarantees internal consistency between the estimation of the hours and the earnings equations. Furthermore, information on hours and weekly earnings has a higher response rate than the self reported wage rate. The response rate for

\footnotetext{
${ }^{2}$ There is some ambiguity about whether or not helping out a friend or relative is a portfolio decision. There were only 5 individuals in our final sample of 70 who listed this reason. Because of the small sample size we chose to include these observations.
} 
weekly earnings is already lower than for the other variables. Using the self reported information on the wage would have meant an even larger reduction in the number of valid observations.

The non-labor income variable I measures the maximum potential level of non-labor income. Typically, non-labor income is defined as family income minus family labor earnings. However, the CPS does not report family income in continuous dollar figures but rather in income brackets. Hence, we imputed the individual family income to be equal to the upper bound value of the income brackets. We divided this imputed value of maximum family income by 52 and we subtract from this value the amount of reported weekly family earnings minus earnings reported on the second job. As reported in Averett (2001), the CPS apparently did not include earnings on the second job in reported weekly family earnings. Surprisingly the raw values of the non-labor income variable was negative for over half of the individuals in our sample. Given that we use maximum potential family income, we expected our variable to overestimate the real value of weekly non-labor income. In theory, there is no reason to believe that non-labor income always has to be positive. A negative value for non-labor income implies that the family is in a net debtor position. However, except for net income deriving from business, farm, and rent, the other components of family income are not net of family debt, thus making the negative value puzzling. One reason why the raw non-labor income variable turned out to be negative for some individuals is related to the fact that weekly earnings are reported for the current year, while family income refers to the year preceding the interview. The labor earnings growth over time can help to explain why in some cases the difference between family income and labor earning is negative. Our strategy was to impute expected non-labor income to the non-positive limit observations from an estimated tobit model in which nonlabor income is estimated as a function of age and schooling (the estimated tobit model is reported in the appendix). The imputed values for the limit observations 
were calculated as the expected non-labor income conditional on non-labor income being positive weighted by the estimated probability that non-labor income would be positive for the particular limit observation.

The fact that we have completed observations for only 10 percent of the entire sample of dual jobholders for the portfolio motive raises some questions about the generality of our results. However, the comparison of the distributions across industry, occupation, age, and schooling categories computed for the entire sample of dual job holders and for our subsample shows that the characteristics of dual jobholders are quite similar. These are reported in Table 3. Professional together with executive, administrative, and managerial, and with precision product, craft, and repair are the occupations that account for more than 60 percent of dual jobholders in both the full sample and the estimation sample. Workers employed in manufacturing, in public administration and education account for the largest percentages of dual jobholders, although the percentages are higher in the estimation sample than in the full sample.

\section{Estimation Strategy and Empirical Results}

A fundamental ambiguity arises with any empirical implementation of a dual labor supply model. For any given individual it is immaterial as to which job is labeled job 1 or job 2. On the other hand, job labeling can make a difference when imposing the dual labor supply model on a sample of workers. What would be the common element across jobs to be assigned the same job label across workers? In the data one can observe the wages and hours for two jobs for dual job holders but on what basis can these be allocated to each of two job labels across workers? In surveys where individuals are freely allowed to identify their main job, there would be some ambiguity because it would not be clear to the researcher how different individuals are identifying their main job. Some might implicitly regard their main job as the one in which they work the most hours over some period. Others might regard the 
main job as the one with the highest wage. Still others might regard the main job as the one in which their earnings are the highest over some period. In the CPS data job 1 (the main job) is identified as the job at which the individual worked the most hours in the reference week. Therefore, this is the convention we follow in this study.

We estimated the Stone-Geary model's boundary parameters $\gamma_{1}, \gamma_{2}$, and $\gamma_{3}$ directly from the sample as $\tilde{\gamma}_{i}=$ the highest integer value that satisfies $h_{i}^{\max }<\tilde{\gamma}_{i} \leq 1+h_{i}^{\max }$, $i=1,2$ and $\tilde{\gamma}_{3}=$ the lowest integer value that satisfies $y^{\text {min }}-1 \leq \tilde{\gamma}_{3}<y^{\text {min }}$, where $h_{i}^{\max }$ is the maximum observed hours of work for job $i$ and $y^{\min }$ is the lowest observed income. Imposing these estimates simplifies the estimation and leads to the following hours and earnings versions of the empirical model:

$$
\begin{gathered}
h_{1 t}-\tilde{\gamma}_{1}=\alpha_{1}\left[\tilde{\gamma}_{3}\left(\frac{1}{w_{1 t}}\right)-\tilde{\gamma}_{2}\left(\frac{w_{2 t}}{w_{1 t}}\right)-\left(\frac{\mathrm{I}_{t}}{w_{1 t}}\right)-\tilde{\gamma}_{1}\right]+u_{h 1} \\
h_{2 t}-\tilde{\gamma}_{2}=\alpha_{2}\left[\tilde{\gamma}_{3}\left(\frac{1}{w_{2 t}}\right)-\tilde{\gamma}_{2}\left(\frac{w_{1 t}}{w_{2 t}}\right)-\left(\frac{\mathrm{I}_{t}}{w_{2 t}}\right)-\tilde{\gamma}_{2}\right]+u_{h 2} \\
w_{1 t}\left(h_{1 t}-\tilde{\gamma}_{1}\right)=\alpha_{1}\left[\tilde{\gamma}_{3}-\tilde{\gamma}_{1} w_{1 t}-\tilde{\gamma}_{2} w_{2 t}-\mathrm{I}_{t}\right]+u_{w h 1} \\
w_{2 t}\left(h_{2 t}-\tilde{\gamma}_{2}\right)=\alpha_{2}\left[\tilde{\gamma}_{3}-\tilde{\gamma}_{1} w_{1 t}-\tilde{\gamma}_{2} w_{2 t}-\mathrm{I}_{t}\right]+u_{w h 2}
\end{gathered}
$$

We first estimated the $\alpha_{i}$ parameters from the simple hours and earnings models by $O L S$. In addition to $O L S$, we consider $S U R$ estimation of the hours equations to allow for covariance between $u_{h 1}$ and $u_{h 2}$ (because the regressors in the earnings equations are identical, $S U R$ is equivalent to $O L S)$. In the case of the $S U R$ hours model, there was virtually no correlation between $u_{h 1}$ and $u_{h 2}$. Based on the Lagrange Multiplier test, we could not reject the hypothesis that the errors in the simple hours model are uncorrelated, hence there is no efficiency gain from using $S U R$. Another estimation strategy we pursued was to take account of selection among dual job holders who are not constrained in their choice of hours versus those dual job holders who 
are constrained. Here, the variables included in the selection equation were a constant, age, schooling, race, the number of children under the age of 18, and non-labor income. For the hours model, the $M L E$ did not converge. In the case of the earnings model, the $M L E$ results produced statistical significance only for the constant term and age in the selection equation and yielded estimates of the $\alpha$ parameters that were virtually equal to zero.

As an attempt to take account of heterogeneity in the utility function, we included in the hours and earnings models additional regressors such as a constant, age, age squared, and schooling (race was never statistically significant). In the case of the hours model, the estimated $\alpha$ parameters were virtually zero. For the earnings model, the estimated $\alpha$ parameters yielded elasticities very similar to those computed from the model without demographic controls. The major difference is that the elasticities on the first job were somewhat lower and on the second job were somewhat higher compared with the results from the earnings model without demographic controls. Although schooling was not statistically significant, the estimated age profiles suggest that labor supply as measured by weekly earnings tended to rise after the age of 44 in job 1 and tended to fall after the age of 46 in job 2. This would indicate a shifting preference toward the primary job in the latter part of a dual job holder's working life.

Our basic results leave us with three candidate empirical dual labor supply models: 1) $O L S$ applied to the simple hours model; 2) $O L S$ applied to the simple earnings model; and 3) OLS applied to the earnings model with demographic control variables. These estimated models are reported in the statistical appendix.

Tables 4 reports the estimated labor supply elasticities for the simple hours and earnings models. These elasticities are calculated at a) the sample means, b) at the sample medians, c) at the sample averages of the individually predicted elasticities, and d) at the sample medians of the individually predicted elasticities. A number 
of conclusions emerge from the results. The uncompensated and compensated labor supply curves are positively sloped for both jobs. Each job's wage rate (both compensated and uncompensated) has a negative effect on labor supply to the other job. Pure income effects are negative for both jobs as well as the compensated own wage and cross-wage effects. The labor supply elasticities for job 2 generally exceed those for job 1, sometimes dramatically so. Perhaps the $O L S$ estimated hours functions yield the most plausible magnitudes for the $\alpha_{1}$ and $\alpha_{2}$ parameters as evidenced by the estimated elasticities. Evaluated at the sample mean, a 10\% increase in the wage for job 1 would increase labor supply to job 1 by $2.3 \%$ and reduce labor supply to job 2 by $5.5 \%$. On the other hand a $10 \%$ increase in the wage for job 2 would raise labor supply to job 2 by $5.4 \%$ but reduce labor supply to job 1 by $2.3 \%$. A $10 \%$ increase in non-labor income would reduce labor supply to jobs 1 and 2 by $0.3 \%$ and $0.4 \%$ respectively. Evaluated at the mean, a compensated $10 \%$ rise in the own wage would raise labor supply to job 1 by $4.7 \%$ and by $6.4 \%$ to job 2 .

\section{Concluding Remarks}

In this paper we presented a model of dual job holding for non constrained workers. We derive the labor supply to both jobs using the Stone-Geary utility function. Both hours and earnings equations are estimated. We found that the labor supply to job 2 is more responsive than the labor supply to job 1 to changes in wages. Because of the generally completely offsetting influences of uncompensated own and cross-effects, our results suggest that a proportionate change in the wage rates for both jobs would leave total labor supply unchanged. This lends some support to the usual argument that changes in the income tax system have no effect on labor supply, at least as far as the effects of marginal tax rates on wages are concerned. On the other hand, the combined effect of say a $10 \%$ rise in non-labor income would reduce total labor supply according to the hours model by as much as $23 \%$ based on averaging individual 
estimated income elasticities.

The extensive literature on male labor supply has consistently found very small elasticities, at times even equal to zero. In line with the current literature, this study estimates small and negative pure income elasticities (between -0.02 and -0.06), and small and positive compensated wage elasticity (between 0.4 and 0.5 ) for job 1 of a dual jobholder. This is not surprising, since we set job 1 to be the job that the CPS defined as the main job, which is the job that one would assume is typically used in the estimation of labor supply ${ }^{3}$. Interestingly, our study finds that the income and compensated wage elasticities are much larger for labor supply to job 2 . In fact we found that the pure income elasticity to job 2 is still negative and inelastic but the compensated wage elasticity varies from a low of 0.6 to a high of 1.8 , depending on where the model is evaluated.

Extensions of this work might include taking into account the possible effects of wage rates (potential or realized) of other family members on one's labor supply to each job. One might also consider developing a dynamic model of dual labor supply. Empirical implementation of such a model would require panel data. Additional complications arise here because what is considered as job 1 by an individual in a given period might appear as job 2 in another period.

\footnotetext{
${ }^{3}$ In data sources such as the decenial Census, hours worked are often calculated as the product of hours worked in the reference week multiplied by weeks worked in the past year. This is in turn divided into annual earnings to obtain an average hourly wage. Among other problems, this method aggregates over multiple jobs in obtaining labor supply and hourly wage measures.
} 


\section{REFERENCES}

Abdukadir, Gulnaz. 1992. "Liquidity Constraints as a Cause of Moonlighting", Applied Economics, v. 24, n. 12, 1307-10.

Allen, W. David. 1998. "The moonlighting decision of Unmarried Men and Women: Family and Labor Market Influences", Atlantic Economic Journal, v. 26, n. 2, $190-205$.

Averett, Susan. 2001. "Moonlighting: Multiple Motives and Gender differences", Applied Economics, v. 33, n. 11, 1391-141

Campbell, James. 2003. "Multiple jobholding in States, 2002", Monthly Labor Review, v. 126 , n. 11-12, 20-21.

Chung, Jae Wan. 1994. "Utility and production functions : theory and applications", Cambridge, Mass., USA : Blackwell.

Kimmel, Jean and Convay Karen S. 1998. "Male Labor Supply Estimates and the Decision to Moonlight", Labour Economics, v. 5, n. 12, 135-66.

Kimmel, Jean and Convay Karen S. 2001. "Who Moonlights and Why? Evidence from the SIPP”, Industrial Relations, v. 40, n. 1, 89-120.

Kimmel, Jean and Lisa Powell. "Moonlighting trends and Related Policy Issues in Canada and in the United States", Canada Public Policy , v. 25, n. 2, 207-31.

Krishnan, Pramila. 1990. "The Economics of Moonlighting: A Double Self-Selection Model" The Review of Economics and Statistics, 361-367.

Paxson, Christina H. and Sicherman Nachum. 1996. "The Dynamics of Dual Job Holding and Job Mobility", Journal of Labor Economics, v. 14, n. 3, 357-393. 
Shisko, R. and Rostker, Bernard D. 1976. "The Economics of Multiple Job Holding", American Economic Review, v. 66, n. 3, 298-308. 
Table 1: Motivation for working on two jobs

\begin{tabular}{lc}
\hline \hline Motivation & \# of observations \\
\hline 1) To meet regular household expenses & 494 \\
2) to pay off debts & 125 \\
3) to save for the future & 149 \\
4) to get experience in a different occupation or to & 152 \\
built up a business & 56 \\
5) to help out a friend or relative & 89 \\
6) to get extra money to buy something special & 324 \\
7) enjoys the work on the second job & 5 \\
8) changed jobs during the week & 205 \\
9) other & 35 \\
10) NA
\end{tabular}


Table 2: Variable Description

\begin{tabular}{llcccc}
\hline \hline Variable & Definition & Mean & Median & Min & Max \\
\hline $\mathrm{h}_{1}$ & Hours worked on job 1 & 44.2571 & 40 & 20 & 80 \\
$\mathrm{~h}_{2}$ & Hours worked on job 2 & 12.6857 & 10 & 1 & 40 \\
$\mathrm{I}$ & Non-labor income & 93.9865 & 47.714 & 4.93445 & 616.538 \\
$\mathrm{~W}_{1} \mathrm{~h}_{1}$ & Earnings on job 1 & 688.243 & 600 & 100 & 1923 \\
$\mathrm{w}_{1}$ & Wage rate on job 1 & 15.4211 & 14 & 3.33333 & 42.8571 \\
$\mathrm{w}_{2} \mathrm{~h}_{2}$ & Earnings on job 2 & 184.857 & 100 & 7 & 1927 \\
$\mathrm{~W}_{2}$ & Wage rate on job 2 & 16.5717 & 10.208 & 1.4 & 75 \\
$\mathrm{AGE}$ & Age of respondent & 42.6429 & 42.5 & 20 & 71 \\
$\mathrm{SCHOOL}$ & Years of education & 13.2 & 13 & 1 & 17 \\
\hline \hline
\end{tabular}


Table 3. Distribution of Dual Jobholders

\begin{tabular}{|c|c|c|c|}
\hline & & $\begin{array}{c}\text { Full Sample } \\
n=737\end{array}$ & $\begin{array}{l}\text { Estimation Sample } \\
n=70\end{array}$ \\
\hline \multicolumn{4}{|l|}{ Industry } \\
\hline & Agriculture & $3.26 \%$ & $4.29 \%$ \\
\hline & Mining & $0.95 \%$ & $0.00 \%$ \\
\hline & Construction & $5.56 \%$ & $1.43 \%$ \\
\hline & Manufacturing -- Durable Goods & $13.98 \%$ & $17.14 \%$ \\
\hline & Manufacturing -- Non-Durable Goods & $8.28 \%$ & $10.00 \%$ \\
\hline & Transportation & $4.61 \%$ & $4.29 \%$ \\
\hline & Communications & $0.81 \%$ & $0.00 \%$ \\
\hline & Utilities and Sanitary Services & $2.99 \%$ & $4.29 \%$ \\
\hline & Wholesale Trade & $4.34 \%$ & $1.43 \%$ \\
\hline & Retail Trade & $7.19 \%$ & $8.57 \%$ \\
\hline & Finance, Insurance, and Real Estate & $6.11 \%$ & $4.29 \%$ \\
\hline & Business, Auto and Repair Services & $6.92 \%$ & $2.86 \%$ \\
\hline & Personal Services & $0.68 \%$ & $0.00 \%$ \\
\hline & Entertainment And Recreation Services & $1.49 \%$ & $0.00 \%$ \\
\hline & Hospitals & $2.44 \%$ & $0.00 \%$ \\
\hline & Medical Services, except Hospitals & $2.17 \%$ & $1.43 \%$ \\
\hline & Educational Services & $11.94 \%$ & $20.00 \%$ \\
\hline & Social Services & $0.68 \%$ & $1.43 \%$ \\
\hline & Other Professional Services & $5.02 \%$ & $2.86 \%$ \\
\hline & Forestry And Fisheries & $0.54 \%$ & $1.43 \%$ \\
\hline & Public Administration & $10.04 \%$ & $14.28 \%$ \\
\hline \multicolumn{4}{|l|}{ Occupation } \\
\hline & Executive, Administrative, \& Managerial & $19.95 \%$ & $8.57 \%$ \\
\hline & Professional Specialty & $24.69 \%$ & $34.29 \%$ \\
\hline & Technicians And Related Support & $4.07 \%$ & $2.86 \%$ \\
\hline & Sales & $8.55 \%$ & $8.57 \%$ \\
\hline & Administrative support including Clerical & $5.29 \%$ & $7.14 \%$ \\
\hline & Protective Service & $3.66 \%$ & $4.29 \%$ \\
\hline & Service excluding Protective & $2.99 \%$ & $2.86 \%$ \\
\hline & Precision Prod., Craft \& Repair & $14.65 \%$ & $17.14 \%$ \\
\hline & Machine operators, assemblers \& inspecto & $4.21 \%$ & $4.29 \%$ \\
\hline & Transportation and Material Moving & $4.61 \%$ & $1.43 \%$ \\
\hline & Handlers, equip cleaners, helpers, laborers & $3.53 \%$ & $4.29 \%$ \\
\hline & Farming, Forestry And Fishing & $3.80 \%$ & $4.29 \%$ \\
\hline \multicolumn{4}{|l|}{ Age } \\
\hline & $<=25$ & $3 \%$ & $6 \%$ \\
\hline & between 25 and 55 & $83 \%$ & $81 \%$ \\
\hline & $>=55$ & $14 \%$ & $13 \%$ \\
\hline \multicolumn{4}{|l|}{ Education } \\
\hline & $<12$ & $32 \%$ & $36 \%$ \\
\hline & 12 & $7 \%$ & $9 \%$ \\
\hline & $>12$ & $51 \%$ & $46 \%$ \\
\hline
\end{tabular}


Table 4: Dual-Job Labor Supply Elasticities

\begin{tabular}{|c|c|c|c|c|c|c|c|c|}
\hline & \multicolumn{4}{|c|}{ Hours Model } & \multicolumn{4}{|c|}{ Earnings Model } \\
\hline & $(1)^{\mathrm{a}}$ & $(2)^{b}$ & $(3)^{c}$ & $(4)^{d}$ & $(5)^{a}$ & $(6)^{b}$ & $(7)^{\mathrm{C}}$ & $(8)^{d}$ \\
\hline \multicolumn{9}{|c|}{ Job 1} \\
\hline$\eta_{11}$ & 0.232 & 0.155 & 0.288 & 0.170 & 0.270 & 0.180 & 0.335 & 0.197 \\
\hline$\eta_{12}$ & -0.233 & -0.175 & -0.277 & -0.182 & -0.271 & -0.203 & -0.322 & -0.211 \\
\hline$\eta_{1 I}$ & -0.032 & -0.020 & -0.059 & -0.017 & -0.037 & -0.023 & -0.069 & -0.020 \\
\hline$\eta_{11}^{c}$ & 0.466 & 0.389 & 0.522 & 0.404 & 0.542 & 0.452 & 0.607 & 0.469 \\
\hline$\eta_{12}^{c}$ & -0.161 & -0.132 & -0.203 & -0.110 & -0.187 & -0.154 & -0.235 & -0.128 \\
\hline$\varepsilon_{11 I}$ & -0.234 & -0.234 & -0.234 & -0.234 & -0.272 & -0.272 & -0.272 & -0.272 \\
\hline$\varepsilon_{12 I}$ & -0.072 & -0.043 & -0.075 & -0.047 & -0.084 & -0.050 & -0.087 & -0.054 \\
\hline \multicolumn{9}{|c|}{ Job 2} \\
\hline$\eta_{21}$ & -0.548 & -1.025 & -1.734 & -0.953 & -1.730 & -3.235 & -5.472 & -3.008 \\
\hline$\eta_{22}$ & 0.547 & 0.982 & 1.752 & 0.943 & 1.728 & 3.098 & 5.530 & 2.975 \\
\hline$\eta_{2 I}$ & -0.041 & -0.043 & -0.174 & -0.049 & -0.130 & -0.137 & -0.550 & -0.156 \\
\hline$\eta_{21}^{c}$ & -0.249 & -0.519 & -0.791 & -0.432 & -0.785 & -1.637 & -2.496 & -1.364 \\
\hline$\eta_{22}^{c}$ & 0.640 & 1.074 & 1.845 & 1.035 & 2.019 & 3.389 & 5.821 & 3.266 \\
\hline$\varepsilon_{21 I}$ & -0.300 & -0.506 & -0.943 & -0.465 & -0.945 & -1.598 & -2.976 & -1.467 \\
\hline$\varepsilon_{22 I}$ & -0.092 & -0.092 & -0.092 & -0.092 & -0.291 & -0.291 & -0.291 & -0.291 \\
\hline
\end{tabular}


Appendix 
Table A1: Estimated Models

(robust standard errors in parentheses)

\begin{tabular}{|c|c|c|c|c|c|c|c|}
\hline \multirow[b]{3}{*}{ Constant } & \multicolumn{2}{|c|}{ Hours Model } & \multicolumn{2}{|c|}{ Earnings Model } & \multicolumn{2}{|c|}{ Earnings with demographics } & \multirow{2}{*}{$\begin{array}{c}\text { Tobit Model } \\
\text { Non-labor Income } \\
\end{array}$} \\
\hline & Job 1 & Job 2 & Job 1 & Job 2 & Job 1 & Job 2 & \\
\hline & - & - & - & - & $\begin{array}{l}713.687 \\
(235.70)\end{array}$ & $\begin{array}{c}-1032.61 \\
(310.44)\end{array}$ & $\begin{array}{c}-146.221 \\
(159.82)\end{array}$ \\
\hline$\alpha_{1}$ & $\begin{array}{c}0.2341 \\
(0.0259)\end{array}$ & - & $\begin{array}{c}0.2719 \\
(0.0179)\end{array}$ & - & $\begin{array}{c}0.1946 \\
(0.0367)\end{array}$ & - & - \\
\hline$\alpha_{2}$ & - & $\begin{array}{c}0.0923 \\
(0.0194)\end{array}$ & - & $\begin{array}{c}0.2912 \\
(0.0375)\end{array}$ & - & $\begin{array}{c}0.4202 \\
(0.0904)\end{array}$ & - \\
\hline Age & - & - & - & - & $\begin{array}{l}-34.9048 \\
(12.0450)\end{array}$ & $\begin{array}{l}54.3254 \\
(14.999)\end{array}$ & $\begin{array}{l}10.8546 \\
(2.9241)\end{array}$ \\
\hline Age_sq & - & - & - & - & $\begin{array}{c}0.4007 \\
(0.1451)\end{array}$ & $\begin{array}{l}-0.5925 \\
(0.1728)\end{array}$ & - \\
\hline School & - & - & - & - & $\begin{array}{r}-14.3676 \\
(8.7496) \\
\end{array}$ & $\begin{array}{r}13.7979 \\
(19.621) \\
\end{array}$ & $\begin{array}{r}-30.0429 \\
(9.8699) \\
\end{array}$ \\
\hline
\end{tabular}


Table A2: Elasticities from earnings model with demographics

\begin{tabular}{lcccc}
\hline \hline Job 1 & $(1)^{\mathrm{a}}$ & $(2)^{\mathrm{b}}$ & $(3)^{\mathrm{c}}$ & $(4)^{\mathrm{d}}$ \\
$\eta_{11}$ & 0.193 & 0.129 & 0.240 & 0.141 \\
$\eta_{12}$ & -0.194 & -0.145 & -0.230 & -0.151 \\
$\eta_{1 I}$ & -0.027 & -0.017 & -0.049 & -0.014 \\
$\eta_{11}^{c}$ & 0.388 & 0.323 & 0.434 & 0.336 \\
$\eta_{12}^{c}$ & -0.134 & -0.110 & -0.168 & -0.091 \\
$\varepsilon_{11 I}$ & -0.195 & -0.195 & -0.195 & -0.195 \\
$\varepsilon_{12 I}$ & -0.060 & -0.035 & -0.062 & -0.039 \\
& & & & \\
Job 2 & & & & \\
$\eta_{21}$ & -2.497 & 4.470 & -7.897 & -4.340 \\
$\eta_{22}$ & 2.493 & -4.668 & 7.980 & 4.292 \\
$\eta_{2 I}$ & -0.188 & -0.196 & -0.793 & -0.225 \\
$\eta_{21}^{c}$ & -1.133 & -2.363 & -3.602 & -1.968 \\
$\eta_{22}^{c}$ & 2.913 & 4.890 & 8.400 & 4.713 \\
$\varepsilon_{21 I}$ & -1.364 & -2.305 & -4.294 & -2.117 \\
$\varepsilon_{22 I}$ & -0.420 & -0.420 & -0.420 & -0.420 \\
& & & & \\
\hline \hline
\end{tabular}

${ }^{\text {a }}$ Elasticities evaluated at the sample means

${ }^{\mathrm{b}}$ Elasticities evaluated at the sample medians

${ }^{c}$ Average elasticities across individuals

${ }^{c}$ Median elasticities across individuals 